\title{
Şeyhülislam Muhammed ve Sâmih’in kudûmiyeleri üzerine mukayeseli bir inceleme
}

\section{Halil BATUR'}

Enes YILDIZ2

\begin{abstract}
APA: Batur, H.; Yıldız, E. (2019). Şeyhülislam Muhammed ve Sâmih’in kudûmiyeleri üzerine mukayeseli bir inceleme. RumeliDE Dil ve Edebiyat Araştırmaları Dergisi, (14), 259-288. DOI: $10.29000 /$ rumelide.541019
\end{abstract}

\section{$\ddot{O} \mathbf{z}$}

Divan edebiyatının altı yüz yıllık gelişiminde farklı nazım şekilleri ve türlerine rastlamak mümkündür. Klasik Türk edebiyatının şeklî kuralcı yapısı içerisinde siyasî ve kültürel ortamın etkisi, sanatçıların yenilik arayışı ve estetik kaygıları gibi nedenlerle yeni türler ortaya çıkmıştır. Klasik edebiyatımızda "sefer, teşrif ve tebrik" temelli türlerden biri de kudûmiyelerdir. Kudûmiye; büyük ve önemli zâtların bir seferden avdeti veya bir şehre teşrifi vesilesiyle takdim olunan armağana denir. Edebî bir terim olarak kudûmiye; büyük ve önemli bir zâtın seferden dönmesi veya bir şehre teşrifi vesilesiyle yazılan, avdetin veya teşrifin tebrik edilip şairin ve halkın üzerindeki duyguların yansıtıldığı, dönen veya teşrif eden kişinin methedildiği manzumelere denir. Bu çalışma 17. yüzyl sanatçılarından Şeyhülislam Hocazâde Mehmed Efendi ve 19. yüzyıl sanatçllarından Mehmed Sâmih'in kaside nazım şekliyle yazdıkları kudûmiyelerin mukayeseli olarak incelenmesinden oluşmaktadır. Çalışmada öncelikle klasik Türk edebiyatında kudûmiyeler ve kudûmiyelerin diğer türlerle ilişkisi hakkında bilgi verilmiş, ardından farklı yüzyıllarda yazılmış ve farklı kişilere sunulmuş iki kudûmiye, şekil ve muhteva açısından incelenmiştir. Yazının sonunda iki kasidenin transkripsiyonlu metni de verilmiştir.

Anahtar kelimeler: Klasik Türk edebiyatı, kudûmiye, Şeyhülislam Muhammed, Sâmih.

\section{A comparative investigation on Sheikh al-Islam Muhammed and Samih's kudumiyes}

\begin{abstract}
It is possible to find different forms and types of divan literature in its six hundred years of development. Within the prescriptive structure of classical Turkish literature, new species emerged with the effect of political and cultural environment, artists' quest for novelty and aesthetic concerns. In our classical literature, one of the species based on ud "expedition, honour and greeting"is kudumiye. Kudum to; the great and important person is called a gift or a gift that is presented to a city. As a literary term, kudumiye is called poems, in which a great and important person is returned from the expeditionor written on the occasion of his dissemination to a city, where he is congratulated, the emotions on the poet and the public, and the person returning or praising is praised. This study consists of comparative study of the 17th century Shaykh al-Islam Mehmed Efendi and the 19 th century Mehmed Sâmih in the form of kasida. In this study, firstly some information

1 Dr. Öğrencisi, Dicle Üniversitesi, Sosyal Bilimler Enstitüsü, Türk Dili ve Edebiyatı ABD, (Diyarbakır, Türkiye), halilbaturr@gmail.com, ORCID ID: 0ooo-0002-7742-6339 [Makale kaylt tarihi: 21.02.2019-kabul tarihi: 13.03.2019; DOI: 10.29000/rumelide.541019]

2 Dr. Öğrencisi, Çukurova Üniversitesi, Sosyal Bilimler Enstitüsü, Türk Dili ve Edebiyatı ABD, (Adana, Türkiye), enesedebiyat@hotmail.com, ORCID ID: 0000-0003-3614-579X
\end{abstract}




\begin{abstract}
about kudumiye and the relation betweenother species in classical Turkish literature. Will be given and the two kudûmiye written in different centuries and presented to different people will be examined in terms of form and content. At the end of the article, the transcribed text of both kasidas will be given.
\end{abstract}

Key words: Classical Turkish literature, kudumiye, Shaykh al-Islam Muhammed, Samih.

\title{
Giriş
}

Türk edebiyatının tarihî gelişiminde divan edebiyatı, klasik Türk edebiyatı, eski Türk edebiyatı gibi farklı adlarla anılan; nazım şekilleri, nazım türleri ve tarzları, sanatçıları ve edebî-kültürel arka planıyla yaklaşık altı yüzyıl süren edebî bir gelenek oluşmuştur. Divan edebiyatının altı yüzyıllık gelişiminde farklı nazım şekilleri ve türlerine rastlamak mümkündür. Klasik Türk edebiyatının şeklî kuralcı yapısı içerisinde siyasî ve kültürel ortamın etkisi, sanatçlların yenilik arayışı ve estetik kaygılarla yeni türler ortaya çıkmıştır. İşte klasik edebiyatımızda "sefer" ve "tebrik” temelli türlerle birlikte gördüğümüz, farklı nazım şekilleriyle yazılan bir tür kudûmiyelerdir. Kudûm; "gelme, uzak bir mahalden veya uzun bir yoldan gelip yetişme, vüsûl, muvâsalât, uzak bir yoldan, uzak bir yerden gelme, ayak basma" demektir (Sami, 2009: 1059; Devellioğlu, 2004: 525). Kudûmiye ise büyük ve önemli bir zâtın seferden avdeti vesilesiyle takdim olunan armağana denir. Edebî bir terim olarak ise kudûmiye; büyük ve önemli bir zâtın seferden dönmesi veya bir şehre teşrifi vesilesiyle yazılan, avdetin veya teşrifin tebrik edilip şairin ve halkın duygularının yansıtıldığı, dönen veya teşrif eden kişinin methedildiği manzumelere denir. "Bugünkü bilgilerimize göre kudûmiye Türk edebiyatındaki varlığını ilk olarak 14. yüzyılda göstermiştir. Ahmedî tarafindan yazılan bir kudûmiye örneğiyle beraber türün ortaya çıtığını söyleyebiliriz. 15. ve 16. yüzyllarda çeşitli şairler tarafindan bu türde örnekler verilmiştir. Kudûmiye asıl ilerlemesini 18. ve 19. yüzyıllarda kaydetmiştir. 18. ve 19. yüzyılların genel özelliklerine baktığımızda bir edebî tür zenginliği görülür. Bu zenginliğin sebebi olarak, zikredilen yüzyıllarda şairlerin yenilik arayışına girmelerini söyleyebiliriz." (Ertuğrul, 2018:1-2). Kudûmiyeler çoğunlukla kaside ve kıt'a nazım şekliyle, başlıklı veya başlıksız yazılabilir. Kudûmiyelerin başlıklarında "kaside, medh, sitâyiş, senâ, târîh, avdet, fetih, teşrif, kudûmiye, tehniye, âmedî, tevcih, tebrik, tenezzül, geldükde...” gibi kelimelerle karşllaşabiliriz. Başlıklar, şairin tercihine göre nazım şekline, muhtevaya veya kudûmiyeye göndermeler yapabilir.

Tebrik, müjde ve teşrif şiirleri olan kudûmiyeler bir seferin sonucunda veya bir şehre teşrif vesilesiyle yazılır. Kudûmiyelerde zafer ve teşriften dolayı halkın ve şairin mutluluk ve coşkusu şiirin kurmaca dünyasında, şairin sanat gücüne bağlı olarak teşbih, mecaz ve hüsn-i talil gibi sanatlarla terennüm edilir. Kudûmiyeler başta "cenknâme, gazâvâtnâme, sefernâme, fetihnâme, zafernâme" gibi "sefer" temelli türler olmak üzere bazı türlerle ilişkilidir. Kudûmiyeler "sefer" temelli türlerde beyit/beyitler düzeyinde bir bölüm olabileceği gibi çalışmamıza konu olan kudûmiyelerden Sâmih’in kasidesinde olduğu gibi sadece seferden dönüşü konu alan müstakil manzumeler olarak da karşımıza çıkabilir. Kudûmiyelere benzeyen türlerden biri de tebriknâmelerdir. "Edebî bir terim olarak tebriknâme; akraba, dost, devlet büyükleri, dinî şahsiyetler ve saygın kişilere doğum, sünnet, evlilik, terfi, dinî törenler (bayram, hacdan dönüş, lihye), cülûs, shhhat bulma, zafer, kudûm (uzak bir yerden teşrif), yeni bir yapı inşa etme, satın alma, var olan bir yapının onarılması, yeni yıl vb. vesilelerle sunulan manzum veya mensur eserdir." (Tuğluk, 2010: 42). Kudûmiyelerde de memduhun seferden dönmesi veya bir şehre teşrifi kutlanıp tebrik edilir. Kudûmiyelerde tebrik ile birlikte zafer ve teşrif için "hamd" edilir ve gelen kişi klasik Türk edebiyatı methiye geleneğine göre övülür. Methiyeler memduhun makamı, şairin sanatkârlığı ve halkın memduhta görmek istediği evsafa göre çeşitlilik gösterir. Klasik Türk edebiyatı methiye geleneğine uygun olarak kıyas, özdeşlik ve üstün görme, kudûmiyelerde de görülür ve bu ilişkiler esnasında 
birtakım isimler sayılır. Bu isimler; Hz. Muhammed, Hz. İsa, Hz. Süleyman, Hz. Davut, Hz. Hızır, Hz. Ali ve Hz. Ömer vb. gibi dinî şahıslar olabildiği gibi; Ferîdûn, Cem, Eflatun, Nûşîrevan, İskender vb. gibi tarihî-mitolojik kişiler de olabilir. Şairler memduhu; dinî, tarihî ve mitolojik şahıslarla karşılaştırma, benzetme ve üstün görme yoluna gittiği zaman bu şahısları alâmet-i fârikaları olan vasıfları ile ele alır. Genel olarak bakıldığında kudûmiyelerin "methiye bölümlerinde adalet, lütuf, kerem, cömertlik, kahramanlık, re'y ve tedbir gibi iyi bir yöneticide ve iyi bir insanda bulunması gereken ideal niteliklere yer verildiği görülmektedir." (Aydemir, 2004, s, 411). Aşağıda Bâkî’nin Sultan Süleyman ve Sultan Mehmed’in seferden dönüşü üzerine yazdığı kudûmiyelerden birer parça verilmiştir:

\section{Der-tehniye-i kudûm-i Sultân Süleymân Hân ez sefer-i huceste-eser}

İtdi şehri şeref-i makdem-i Sultân-ı cihân

Reşk-i bâg-ı İrem ü gayret-i gülzâr-ı cinân

Şâdmân oldı bugün devr-i kühen-sâl yine

Vuslat-ı Yûsuf ile niteki pîr-i Ken’ ân

Rûşen oldı açlup dîde-i Ya'kûb-ı emel

Demidür menzil-i ‘işret ola Beytü’l-ahzân

Ol zamân irdi ki biñ şevk ile tâvûs-ı neşât

İde sahn-ı harem-i bâg-ı cihânda cevlân

Husrev-i Cem-'azamet dâver-i Hâkân-satvet

Belki en kem kulı Cem 'abd-i hakîri Hâkân

Dâver-i devr-i zamân Şâh Süleymân ol kim

Yüz sürer pây-i semendine mülûk-i devrân

Şâh-1 Cemşîd-haşem Husrev-i hurşîd-'alem

Ser ü ser-dâr-ı ser-efrâz-ı selâtîn-i zamân (Küçük, 2017: 5)

\section{Der-tehniye-i cülûs-ı Sultân Mehemmed Hân}

Minnet Cenâb-ı Hakka dem-â-dem hezâr-bâr

Fasl-ı şitâda bâg-ı cihân buldı nev-bahâr

Gün gibi tâc-1 devlet-i şâhî tulû̀' idüp

Kevn ü mekâna virdi ziyâ âfitâbvâr

Hûrşîd gibi pertev-i cûd u sehâ ile

Rûy-1 zemîne saçdı zer-i kâmilü’l-'ayâr 
Kıldı zemîni berf gibi nakdi sîme gark

İn’âm-1 ‘ âm-1 şâh-1 cevân-merd-i bahtyâr (Küçük, 2017: 20)

Kudûmiyelerle ilişkili türlerin başında şehir şiirleri gelir. Memduh "av, gezinti, vazife veya sefer" gibi nedenlerle bir şehre gittiklerinde şairler bu teşrifi kutlamak, hediye sunmak, gelen kişiyi övmek ve memduhtan yardım istemek için kudûmiyeler sunmuşlardır. Bu şiirlerde teşriften duyulan mutluluk yanında, gelen kişiye şehri tanıtmak amacıyla şehirle ilgili bilgiler de verirler. Şairler teşrifiyelerinde aynı zamanda şehri methederler, şehri ve insanlarını çeşitli vesilelerle manzumelerinde konu edinirler ve böylece en güzel "hoş geldin/hoş âmedî" hediyelerini sunmaya çalışırlar. Aşağıda Nef̂̂̀nin, Sultan Murat'ın Edirne’ye teşrifi üzerine yazdığı gazel şeklindeki kudûmiyesi verilmiştir:

Nice dilşâd olmasınlar şeyh u şâb-ı Edrine

Şehri teşrîf etdi Şâh-ı kâm-yâb-ı Edrine

Sâyesinde şenliğe yüz tutdu sertâser yine

Oldu yeksân cây-ı ma'mûr u harâb-ı Edrine

Ol kadar etdi sirâyet feyz-i hulk u meşrebi

Kevser ü müşk oldu hep âb u türâb-ı Edrine

Nükhet-i hulkuyla hoş-bûy oldu hâki ol kadar

Rûmu Çîn etdi şemîm-i müşk-nâb-ı Edrine

Meşreb-i şûhunda bir sır var ki te'sîr eylese

Zâ’i olmaz haşre dek keyf-i şarâb-ı Edrine

Yaraşır Nefî̀ bu şi'r-i âbdârî ‘âleme

Ber-güzâr eylerse mânend-i gülâb-ı Edrine

Açdı hurrem etdi zîra gül gibi endişesin

İltifât-ı pâdiş̧âh-ı Cem-cenâb-ı Edrine

Makdemiyle Edrine tahtın müşerref edeli

Oldu her iklîme gâlib âb u tâb-ı Edrine

Hazret-i Sultân Murâd-ı kâmrân kim hak vere

Eyleye devletle zevk-i bî-hisâb-1 Edrine (Akkuş, 1993:337-338)

Kudûmiyelere ilişkili türlerden biri de bahariyelerdir. Bazı kudûmiyelerde memduhun teşrifi ve zeferle dönüşü, şairler tarafından bahar ve baharla ilgili unsurlar üzerinden anlatılır. Büyük bir zâtın seferden zaferle dönmesi ve şehre teşrifi, cihanın taze can bulmasıyla eş değerdir. Onların ayak basmalarıyla kara kış günleri gider, bahar mevsimi hâkim olur. Özellikle hüsn-i talil sanatıyla baharın gelişi, cihanın 
yemyeşil oluşu, güneşin parlaklığı, çiçeklerin açması hepsi memduh ile ilişkilendirilir. Aşağıda dönemin padişahının Edirne’ye teşrifi üzerine Aklî̉ ve Behcetî’nin kudûmiyelerinden birer parça verilmiştir:

\section{Kașide-i 'Akli}

Maḳdemüñden șaḥn-1 gülş̧ende șabā çün urdı dem

Gülşen oldı bülbüli dāstān-serā ḳıldı neg̉am

Bu ṣefādan ṣaḥn-1 gülzāra irişdi dem ḳadem

Ḥayderiler gibi çekdi ser ü ‘ abbāsì ‘ alem

Ḩayr maḳdem merḥabā hoş geldüñ ey şāh-1 kerem

Ey gül-i gülzār-1 devlet gülbün-i bāg̀-1 İrem

Zeyn olup rengīn şükūfeyle donandı sebze-zār

Rūz-i nevrūz oldı şādi ile țoldı her diyār

Açdı zanbaḳ ḥoḳkasın gülşende oldı müşk-bār

İtdi sünbül bu ṣefādan țurrasını tārumār

Her dimāğı eyledi bu nükhet-i zülf-i nigār

Karşı vardı ḳolların açup didi serv ü çenār

Hayr maḳdem merhabā hoş geldüñ ey şāh-1 kerem

Ey gülistān-1 lețāfet vāli-i vālā-himem

Na`l-i esbüñ çün meh-i nevden yine virdi nişān

' $\overline{\text { Id}}$-i nevrūz oldı diyü gülşen oldı şādumān

Giydi gülgūn cāmeler țonandı mīr-i ‘ āşıḳān

Lāleler rengīn țabaḳla oldılar gevher-feşān

Bag̉ladı gül desteler șunmağa şāh-1 ergevān

Cūylar her sū aḳup ayaġuña dirler revān

Huayr maḳdem merḥabā hoş geldüñ ey şāh-1 kerem

Ey şeh-i dānā vü ‘ādil șāhib-i seyf ü ḳalem

\section{Kaside Der-vasf-ı Bâz-Âmeden Sultân-1 Sikender-serîr Be-Mahrûsa-i} Şehr-i Edirne-i Dil-pezîr

Sepîde-dem ki cihân reşk-i nev-bahâr oldı

Açıldı gonca-i âmâl hande-kâr oldı 
Bu demde gülşen-i âmâle reng-i subh-ı şitâ

Ziyâ-yı humret-i mihr ile lâle-zâr oldı

Şükûfe oldı çemen-zâr-ı 'âlem-i şâdi

Nümûne-i sanem-i şûh-ı gül'izâr oldı

Zihî dem-i ferah-efzâ ki feyz-i makdemden

Zemîn-i tâze-zamân bâg-ı pür-hezâr oldı

Bu dem ki makdem-i nevrûz-ı mihr-i devletdür

Riyâz-i gülşen-i 'âlem behişt-zâr oldı

Bu dem ki burc-1 Hameldür Edirne bir mihre

Gelince ana cihân gûyiyâ bahâr oldı (Ölmez, 1996: 288)

Bazı kudûmiyelerde seferden dönüş veya teşrifin tarihi verilebilir veya sadece dönüş ve teşrif için tarih manzumeleri yazılabilir. Bu açıdan tarih düşülen kudûmiyeleri tarih manzumeleri başlı̆̆ı ile de okuyabiliriz. Çalışmamıza konu olan Sâmih'in kudûmiyesinde Mustafa Paşa'nın Sırp meselesini halledip dönüşüne son beyitte tarih düşülmüştür. Buna göre Mustafa Paşa 1279 tarihinde seferden dönmüştür:

Çıḳdı bir tārihh hāmem söyledi müjde diyüp

Muștafā Pāşā-yı ' ālì-nām ' avdet eyledi （Sene H. 1279/M. 1863)

\section{Kudûmiye yazan şairler: Şeyhülislam Muhammed Efendi ve Sâmih4}

\section{1. Şeyhülislam Muhammed5 Efendi}

Üzerinde çalıştığımız "Muhammed" mahlaslı kudûmiyenin kime ait olduğuna dair elimizde sadece başlık ve mahlas vardır. Kasidenin başlığında "Şeyhülislam Muhammed" ibaresi ve 79. beyitte "Muhammed" mahlası bulunmaktadır. Sultan I. Ahmed'in 1603-1617 padişahlık yılları ve 1021 (16121613) yllında Edirne’ye teşrifi düşünüldüğünde bu kişinin Şeyhülislam Hocazâde Mehmet Efendi olduğu anlaşılır. Şeyhülislam Hoca Sadeddin Efendi’nin oğlu olan Mehmet Efendi 1568 yllında Bursa'da doğar. 1568 yllında İsmihan Sultan Medresesinde hocalığa başlar ve Sahn-ı Semân, Yavuz Sultan Selim ve Süleymaniye Medreselerinde görev alır. Mekke ve İstanbul kadılığı, Anadolu kazaskerliği yapar. 1601 yılında şeyhülislam olur ama 1603 yılında görevden azledilir. 1608 yllında yeniden şeyhülislam olan Hocazâde Mehmet Efendi, 1615 yılında vebadan ölür. Toplam şeyhülislamlık süresi 8,5 yıldır (İpşirli, 2003: 452-453).

4 Makale çalışmamı devam ederken Sâmih'in kudûmiyesi üzerine "Mehmet Sâmih’in Üsküp Valisi Müşir Mustafa Paşa Medhiyesi Bağlamında Bir Tarihi Dönem İncelemesi” başlıklı bir çalışmanın yayımlandığını gördük (Çalışkan \& Ünal, 2018: 64-75). Makalenin başlığından da anlaşılacă̆ı üzere çalışmada Sâmih’in kudûmiyesi üzerinden bir dönem incelemesi yapılmıștır. Biz Sâmih’in kasidesi üzerinden bir dönem incelemesi yapılamayacağı düşüncesindeyiz. Çünkü kaside tam bir kudûmiyedir ve seferden sonrasını konu alır. Kaside okunduğunda kudûmiyenin yazılmasına sebep olan dönemin Sırp meselesine sadece ismen atıflar vardır, Sirp meselesiyle ilgili ayrıntıya girilmez. Asıl konu Sirp meselesini halledip dönen Mustafa Paşa'nın makdeminin tebriki, dönemin padişahının ve paşanın methiyesidir. Bu nedenle biz kasidenin "kudûmiye" başlığı altında incelenmesi gerektiğini düşünmekteyiz.

5 Kaynaklarda şairin ismi "Şeyhülislam Hocazâde Mehmet Efendi” şeklinde geçmektedir. Kudûmiyenin başlı̆̆ında ve mahlas beytinde ise "Muhammed" şeklindedir. Biz de çalışmamızda "Muhammed”i tercih ettik. 


\title{
1.2. Nasûhî-zâde Mehmed Sâmih
}

19. yüzyll divan şairlerinden ve Halvetiye'nin Nasuhiye kolunun kurucusu Nasûhî-zâdenin torunlarından Mehmet Sâmih hakkında Tuhfe-i Nâilî’de şu bilgiler yer alır: "Mehmed Sâmih Efendi bin Çavuşzâde Abdulazîz Efendi bin Rumeli Vakâyi-i Şeriye Kâtibi İbrahim Efendi, Üsküdarî Şeyh Nasûhî Efendi ahfadından olmakla Nasûhzâde denmekle meşhûrdur. Vefâtı H.1212, M.1894. Cidde'de medfundur.

\begin{abstract}
Ol zamândan kim ne în ü ân ne dünyâ var idi
Mihr-i zâtımdan sipihr-i feyz-i pür-envâr idi

Mümkinât olmazdan evvel sahâ-pirâ-yı vücûd

Dil rikâbdâr-i semend-i Ahmed-i Muhtâr idi
\end{abstract}

Dâg-ı âteş-tâb-ı dilden renk alır gülzâr-ı dehr

Dûd-ı âh-ı sîneden sûzân olur ezhâr-ı dehr

Derd-i firâk-ı yâr ile nâlânsın ey gönül

Her dem esîr-i pister-i hicrânsın ey gönül

Hemrâz u hemdem olmış idin bir zamân bana

Bâis nedir ki şimdi girîzânsın ey gönül

Sînem misâl-i şâne benim çâk çâk ise

Mânend-i turra sen de perîşânsın ey gönül” (Odabaşı, 2009: 320-321)

Sicill-i Osmanî'de Sâmih hakkında şu bilgiler verilir: "Vekayi kâtibi meşhur Aziz Efendi’nin oğludur. Müderris ve molla olmuş, Medine Mevleviyetini kazanmış, dönüşünde Cidde'de iken 1312 başlarında (1894 yılı ortaları) vefat eylemiştir. Müteşerri' ve ta'lik yazıda zamanın İmâd'ı gibiydi. Şiir ve inşaya mail, iyi huylu bir zât idi.” (Mehmed Süreyya, 1996:1480).

Son Asır Türk Şairleri’nde şairin ataları hakkında bilgi verdikten sonra şunlar söylenir: "Tahsîl-i ilm ettikten sonra 1846'da (H. 1262) tarîk-i tedrise idhâl ve babasının maiyetinde kitâbetle istihdâm olundu. Muahharan Kudüs ve İzmir niyâbetlerinde, İzmir Hukuk riyâsetinde, Girid niyâbetinde, Medîne-i Münevvere Mevleviyetinde bulundu. İkmâl-i müddetle Medîne'den avdetinde 1894'de (1312 H.) Cidde'de vefât etti. Hatt-ı talikde mâhir, nâzım ve nesre kâdir, hüsn-i ahlâk sâhibi olduğu menkuldur. Fatin Tezkiresi’nde bir gazeli mündericdir. Elimizde on gazeli mevcuddur. Diğer âsar-ı nazmiyesi kim bilir nerede kaldı.” İnal bu bilgilerden sonra aşağıdaki “idi” ve "dehr” redifli gazelleri verir:

Ol zamândan kim ne în ü ân ne dünyâ var idi

Mihr-i zâtımdan sipihr-i feyz pür-envâr idi

Olmadan rûh-ı Kelîm ârâyiş-i dîvân-ı Hak

Tûr-1 ma’nâda gönül Sâmih tecellî zâr idi (İnal, 1988: 1671) 
Dâg-ı âteş-tâb-ı dilden renk alır gülzâr-ı dehr

Dûd-ı âh-ı sîneden sûzân olur ezhâr-ı dehr

Sâmihâ bu nev-zemîn-i nazma lâyıkdır eger

Bir nazîre söylese Hakkî-yi hoş-güftâr-ı dehr (İnal, 1988: 1672)

Fatîn Tezkiresi’nde ise şairin “ey gönül” redifli gazelinin tamamı ve ardından mesleği ve ceddi hakkında bilgiler verilir:

Derd-i firâk-1 yâr ile nâlânsın ey gönül

Her dem esîr-i pister-i hicrânsın ey gönül

Hem-râz u hem-dem olmış idin bir zamân bana

Bâis nedir ki şimdi girîzânsın ey gönül

Sînem misâl-i şâne benim çâk çâk ise

Mânend-i turra sen de perîşânsın ey gönül

Merhem-pezîr-i âfiyet olmaz ümidi kes

Mecrûh-ı zahm-ı nâvek-i müjgânsın ey gönül

Tûti-misâl itmedesin güft ü gû her an

Mir'ât-ı hüsn-ı yâre mi hayrânsın ey gönül

Herbir sözünde nükte-i esrâr muhtefî

Müşkil-şinâs-ı âlem-i irfânsın ey gönül

Gelmez hayâl-i Sâmiha âlemde infikâk

Mensûb-ı bâb-ı hazret-i cânânsın ey gönül

"Nâzım-ı mûmâ-ileyh Sâmih Efendi Üsküdar'da defn-i hâk-ı ıtr-nâk olan Şeyh Nasûhî Efendi merhûmun ahfadından vekâyi-i şer‘iyye kâtibi esbak müteveffâ İbrâhim Efendi’nin hafîdi ve hâlâ Rûmeli sadâreti vekâyi-i şer‘iyyesi kâtibi Çavuşzâde Abdulazîz Efendi’nin ferzend-i râşidi olup evkât u ezmânını tahsîl-i maârife hasr u sarf ile bin iki yüz altmış senesi hilâlinde tarîk-i tedrîse dâhil olmuş ve ile’l-ân pederi mümâ-ileyhin maiyetinde umûr-ı kitâbetde müstahdem bulunmuştur.” (Çiftçi, 1996: 209-210).

Sâmih’in kudûmiyesinin sonunda yer alan nesir parçasında da Sâmih ile ilgili şu bilgiler bulunmaktadır:

“Naẓmühā ve raḳamuhā el-faḳirü’l-ḥakịir ilā kerem-i rabbü'l-ḳadīr Naṣūhī-zāde huafīdi merḥūm veḳāyic kātibi İbrāhīm İffet Efendi hyafīdi Es-seyyid Muhammed Sāmiḥ İbn-i Çāvūş-zāde Muhammed 'Azíz el-müderris-i bedārü's-salțanatü's-seniyye el-müvellā-hilāfet-i be-medīne-i Prizren ġaferahüm” 


\section{2. Şeyhülislam Muhammed Efendi ve Sâmih'in kudûmiyeleri}

Şeyhülislam Muhammed Efendi’nin kasidesinin bulunduğu şiir mecmuası Fransa Milli Kütüphanesi, Türkçe yazmalar bölümü 1035 numarada kayıtlıdır. 31,5x21,5 cm. boyutlarındaki mecmua 82 varaktan oluşmaktadır. Mecmua, 2b-3a arası boş olan iki sayfa hariç toplam 162 sayfadır. Mecmuanın 1a sayfasında mecmuayı tertip edenle ilgili "Kerîm olan Allah'ın fakir kulu Muhammed Paşazâde Hacı İbrahim'e ihsanlarından, sene 1322" manasında Arapça bir ibare bulunmaktadır. Tamamına yakını Sultan I. Ahmet methiyesi olan mecmuada farklı nazım şekilleriyle ve türleriyle yazılmış şiirler bulunmaktadır. Şeyhülislam Muhammed Efendi'nin kudûmiyesi mecmuada 23b-29b varaklarındadır.

Sâmih’in kudûmiyesi ise İstanbul Büyükşehir Belediyesi Atatürk Kitaplığı Bel_Yz_K 1488 numaralı şiir mecmuasında bulunmaktadır. 4 varaktan oluşan mecmuada sadece Sâmih'in kasidesi yer alır. Ta'lîk ile yazılan kasidenin sonunda şair hakkında bilgiler veren bir nesir parçası da vardır.

\section{1. Şekil özellikleri}

Şeyhülislam Muhammed Efendi’nin kaside nazım şekli ile yazdığı kudûmiyesi, 83 beyittir ve remel

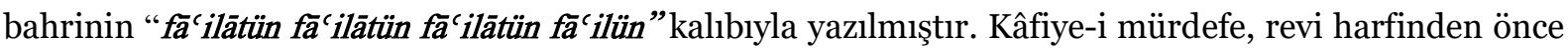
uzun ünlülerden (elif, vav, ye) birinin bulunduğu kafiye türüdür. Şeyhülislam Muhammed Efendi'nin redifsiz kasidesi “-ān” mürdef kafiye ile yazılmıştır. Kudûmiyenin başlı̆̆ı ise "Kașide-i Şeyhü'l-islām Muḥammed Efendi Berāy-1 Sulțān Aḥmed Ḩān" şeklinde olup nazım şekline, şairine ve kim için yazıldığına gönderme yapılmıştır. Kaside, klasik Türk edebiyatında gördüğümüz geleneksel kaside bölümlerini ihtiva etmez. Kasidenin 1-32. beyitleri Sultan Ahmet'in Edirne'yi teşrifi ve orada yaşananları, 33-73. beyitleri sultanın İstanbul'a gelmesi ve 74-83. beyitleri ise dua bölümüdür.

Sâmih'in Mustafa Paşa'ya sunduğu kudûmiye ise 57 beyitten oluşan bir kasidedir. Şair, Şeyhülislam Muhammed Efendi gibi kasidesinde klasik Türk edebiyatı nazım şekillerinde en çok kullanılan

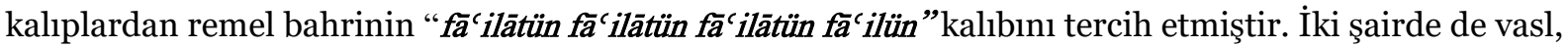
imâle-i maksure ve imâle-i memdûde tasarrufları bulunsa da aruz kullanımı başarılıdır. Kaside " $+\hat{a} t$ eyledi” kafiye ve redifi üzerine kuruludur. Kasidenin 25 beytinde kâfiye-i mü’essese, 22 beytinde de kâfiye-i mücerrede tercih edilmiştir. Kâfiye-i mü'essese revi harfi ile elif arasında harekeli bir ünsüzün yani dahîlin bulunduğu kafiyedir. Kâfiye-i mücerrede ise revi harfinin tekrarından oluşan kafiyedir. Kasidenin redifi ise "eyledi" kelimesidir:

\footnotetext{
'Ālem olmuşken esìr-i pister-i derd ü helāk

Maḳdemi el-ḥakḳ devā-bahşş-1 ifākāt eyledi
}

\section{Āṣafā bende-nüvāzā serverā dād-āverā \\ Zāatuñı mevlā medār-1 kār-1 devlet eyledi}

Sâmih’in kasidesinin de başlı̆̆ı vardır. Sâmih kasidesine Farsça terkip ve Arapça ibarelerden oluşan şöyle bir başlık koymuştur: "Kașide vü Tārih̆-i 'Avdet-i Sa'd-Menkabet-i Kumandān ü Vālì-i Eyālet-i Üsküb Hażret-i Muștafā Paşa 'Māyürídü Mã Yeşā' Ez-Mes 'ele-i Șırp Der-Medine-i Prizren”. Görüldüğü gibi başlıkta hem nazım şekline hem muhtevaya hem de "avdet" kelimesiyle kudûmiye türüne gönderme yapılmış ve avdeti için tarih düşüleceği belirtilmiştir. Methiye kasidelerinin başlı̆̆ında "sitâyiş, senâ, medh, midhat..." gibi kelimeleri görebildiğimiz gibi Sâmih’in başlı̆̆ında olduğu "menkabet" de kullanılır. 
Sâmih başlıkta memduh hakkında bilgiler vermiş ve kasidenin hangi olay üzerine yazıldığını da ifade etmişstir.

Klasik Türk şiirinde tam bir kaside; "nesib/teşbib, girizgâh, methiye, fahriye, tegazzül ve dua" olmak üzere altı bölümden oluşur. Şeyhülislam Muhammed Efendi’nin kudûmiyesinde bu bölümler yokken Sâmih’in kasidesinde bazı bölümler vardır. Kasidenin bölümleri şöyledir: 1.-40. beyitler methiye, 41.48. beyitler fahriye, 49.-53. beyitler tegazzül ve 54.-57. beyitler dua bölümüdür. Sâmih, mahlasını gazelinin beşinci beytinde kullanır. Kasidenin methiye bölümü de kendi içinde iki bölümden oluşur. 1.9. beyitler Sultan Abdülaziz övgüsü, 10.-40. beyitler ise Mustafa Paşa methiyesidir. Methiyeden sonra sekiz beyitte şair kısaca içinde bulunduğu hali tasvir eder ve fahriyesini sıralar. Fahriye beyitlerinden sonra beş beyitlik bir gazel ve kasidenin sonunda dört beyitlik dua bölümü yer alır. Kasidenin sonunda şair hakkında bilgi veren nesir parçası da bulunmaktadır. İki kudûmiyeyi şekil özellikleri açısından mukayese edersek aşağıdaki tablo karşımıza çıkar:

\begin{tabular}{|c|c|c|}
\hline Şeklî Özellikleri & Muhammed Efendi & Sâmih \\
\hline Nazım Şekli & Kaside & Kaside \\
\hline Beyit Sayısı & 83 & 57 \\
\hline Başlık & $\begin{array}{l}\text { Kasạide-i Şeyhüü'l-islām Muhammed Efendi } \\
\text { Berāy-1 Sulțān Ahmed Ḩān }\end{array}$ & 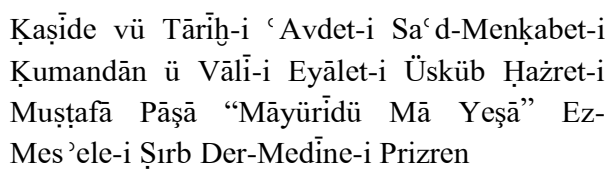 \\
\hline Aruz Ölçüsü & 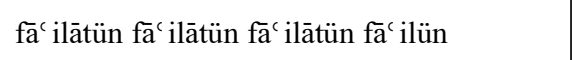 & făcilātün făci ilātün făci ilātün făcilün \\
\hline Redif & - & eyledi \\
\hline Kafiye & Mürdef & Mü'esses ve Mücerred \\
\hline Bölüm & - & $\begin{array}{l}\text { Methiye, fahriye, tegazzül ve dua bölümleri } \\
\text { vardır. }\end{array}$ \\
\hline
\end{tabular}

Tablo 1

\subsection{Muhteva özellikleri}

Hocazâde Mehmet Efendi’nin kudûmiyesinin ilk bölümü padişahın (I. Ahmed) Edirne'ye teşrifi üzerinedir. Şair ilk beyitte "Hayr-makdem merhaba" diyerek zamanın padişahının şehre gelişini müjdeler ve şehre teşrifine duyduğu memnuniyeti ifade eder. Padişahın güneş gibi yüzü, cihanı nurlandırmıştır. Âlem padişahtan ayrılık zulmetinde perişan halde iken kudûm ile vuslatın hayat pınarı görünmüştür. İnsanlar hicrandan söğüt ağacı gibi titrerken padişah şehre teşrif etmiş, böylece lütuf bulutunun döktüğü yağmurla, kalp bağının her köşesi gülistan olmuştur. Bu "makdem” ile gözlerdeki gubâr silinmiş ve gözler parlamıştır. Zamanın ileri gelenleri padişahın ayaklarına yüzlerini izzetle sürmüşlerdir. Padişah âlemin ruhu olduğu için bu makdemle Edirne'nin canı yerine gelmiştir. Sultan Ahmed Han makdemiyle "taht-i kadîme" taze şeref vermiş, köhne hanedan âbâd olmuştur.

Şair 10. beyitle birlikte padişahın Edirne'de neler yaptığını anlatmaya başlar. Padişah şehre girmesiyle hemen camiye gider, "dâr-ı saâdet" içinde bir mescid yaptırılması emrini verir. Daha sonra Tunca 
nehrinde kayık gezintisi yapar. Edirne'nin Osmanlı tarihinde önemli bir yeri de padişahların av merkezi olmasıdır. Sultan Ahmed de seyir ve av için Edirne'nin her yerini gezer. Böylece sultanın himmet atı, devletle ayağını Edirne’ye basmış, atın “na'l-i nakşı” Edirne'yi/yeryüzünü gökyüzü eylemiştir. Seyir ve avdan sonra padişah Gelibolu’ya, Kilit Bahir'e geçer ve iki gün sonra Gelibolu'ya tekrar gelir. Padişah daha sonra Yazıcıoğlu'nu ikram ile ziyaret eder ve doğum günü münasebetiyle mevlit okutturur. Bereket ve uğur için Süleyman Gazi’ye varıp nusret ve fetih kılıcını kuşanan sultan oradan İstanbul'a gelir. Şairin ifadesiyle Sultan Ahmed Edirne'de 5 ay kalmıştır.

Kasidenin 33. beyitle başlayan ikinci bölümü sultanın İstanbul'a teşrifini konu alır. Şair, evvela padişahın İstanbul'a gelişine hamdeder. Padişahın yüzünün nuruyla dua edenlerin gözleri parlamış, din âleminin dâ̂lerinin hepsi eteğine yüz sürmek için gelmişlerdir. Şeref ayının menzili, evvela Küçükçekmece daha sonra da Davut Paşa olmuştur. Muhammed Efendi kasidenin 42. beytiyle padişahın teşrifiyle olanları, şenlikleri tasvir etmeye başlar. Makdemi kutlamak için her yerde mumlardan çadırlar kurulmuştur. Mumlarla süslenen orduyla âdeta yeryüzünde "rusûm-ı ahterân" aşikâr olur. Laleler çemenlikte meşaleler yakmış ve o gecede etrafa ateşler saçmıştır. Teşrif gecesi her yer bayraklarla süslenmiş, şevkten sesler gökyüzüne çlkmış, top ve tüfek sesleri asumanı güm güm etmiştir. $O$ gece firakın zulmet kalesini fethetmek için bütün insanlar ve cinler çalışmıştır. Bütün bunların olması şeref burcunun ayına "Hoş geldin!" demek içindir. İnsanlar saf saf dizilmiştir ve bu manzara mahşeri andırmaktadır. Devlet göğünde aydınlık güneş doğunca cihan nurlanmış, zahmet ve mihnet zulmeti kaybolmuş, bütün devlet erkânı huzuruna gitmiştir. Bahar üzerinden yapılan bazı tasvir beyitleri aşağıda verilmiştir:

Bag̉ladı ṣaflar dırahtān-ı çemen ṣaf saf țurup

Sāye șalar diyü bāga ol ḳad-i serv-i revān

Maḳdem-i sulțān-1 devrāna nisār olsun diyü

Dökdi varın rāh-1 gülzāra nihāl-i erg̉uvān

Ṭaḳınup tīg̀-i zümürrüd-fāmı sūsenlerine

Aldılar debbūslar dūşa mis̄āl-i çāvuşān

Altun üsküf başda destinde zümürrüdden 'așā

Oldı zerrīn saña derbān ey şeh-i sāmī-mekān

Tūg̀-1 şāhı ḳad çeküp açıldı șaḥn-1 bāğda

Ṣanki çözdi perçem-i tūğuñ șabā olup vezān

Mā-ḥașal bu vech ile zīnet bulup șaḥn-1 zemīn

Maḳdemüñ şevkịiyle țonandı şehā ehl-i zamān

Sultan Ahmet, devlet büyüklerini rikâbıyla müşerref ederken yolda Muhammed Efendi’ye de lütufta bulunur. Bu arada bir kâfir aniden Müslüman olacağını söyler ve Muhammed Efendi padişahın huzurunda ona İslam dinini telkin eder. Şair bundan sonra padişaha duaya başlar. Şairin duaları; 
devletin ve padişahın ömrünün uzun olması, devrinde Müslümanların artmasıdır. Şair dua beyitlerinin arasına aşağıda verdiğimiz fahriye beyitlerini de koyar:

Maẓhar-1 ị̣sānuñ olmuşdur Muḥammed serverā

Nola olsa midḥatüñle dā 'imā raṭbü'l-lisān

Çün ider şīīn edālarla hemişse vașfuñ

Dā 'imā olur zebān-1 hāmesi ‘ażbü'l-beyān

Şekker-i şükrüñ neyistānında şekker-ḩā olur

Ḩāmesi țūtịi-ṣıfat olsa nola şīinn-zebān

Zer gibi huāliṣ-` ayār oldur ḩulūṣ-1 ḳalb ile

Ġ1ll ü ġışdan șāf ü pāk olur olursa imtihān

Sâmih kasidesine dönemin padişahı Abdülaziz Han'ı (1861-1867) methederek başlar. Allah, dinini nusretle ihya etmeyi dilemiş ve Abdülaziz Han'ı halka ihsan eylemiştir. Bütün âlem dert ve helâkın esiriyken Allah'ın inayetiyle gelen padişah makdemiyle halka şifa bahşetmiştir. O yüce himmetli, muazzam padişah, lütuf elini halkına gölgelik yapmıştır. Şairin hamdettiği bir konu Abdülaziz Han’ın nusret ve selamet rüzgârının esmesiyle âlem gülşenine tazelik gelmesidir. Padişahın gelmesiyle mülk aynasının üzerinde hiçbir toz kalmamış, gam ve tasa giderek âlem parlaklık kazanmıştır. Abdülaziz Han'ın müceddid olduğuna hiçbir şüphe kalmamıştır. Müceddidliğinin delilleri ise şahit olunun halleridir. Şâhın adaletinin gücü karşısında zulüm ve şer, korkusundan yokluğa karışmıştır. Zamanında kimsenin aklına fitne gelmezken Sirbistan tuğyana cesaret eylemiş, güzel bahtlı Sultan Abdülaziz Han da bu işi halletmesi için Üsküp Valisi Mustafa Paşa’ya emretmiştir.

Vezirlerin veziri Mustafa Paşa Sırp meselesini halletmek için emir almış, padişah tarafından kumandan tayin edilmiştir. Mülkün, tedbir eline emanet edildiği paşa, kılıcını eline almadan düşman itaat eylemiştir. Kahraman kumandan aldığı tedbirler sayesinde birkaç ay içinde Sırp meselesini kolaylıkla halletmiş, Sırplar da bunun karşısında nedamet eylemiştir. Böylece Belgrat kalelerinde halk, düşmandan korkmadan, emin olarak rahat yaşamışlardır. Şefkat madeni Mustafa Paşa hedefe uygun tedbirler ve doğru düşüncelerle ehl-i imanın yerlerini selamet mekânı eylemiştir. Şairin hamdettiği diğer bir konu da paşanın gayretiyle dert ve sıkıntının dünyadan bertaraf olmasıdır. Paşa bu hizmetiyle bulunduğu makamı süslemiş, devlet erkânının şükretmesine vesile olmuştur. Gördüğü bu hizmetle devlet erkânının iftiharı olan paşanın nâmı yücelik divanının, huyu ise kemal ve fazilet mecmuasının başlı̆̆ıyken yaradılışı da "dîbâce-pîrây-ı fetânet” olmuştur. Emirlerini yerine getirmekte kader, hükümlerini icra etmekte kaza sürat eylemişlerdir.

Kasidelerde şairler memduhu birçok sıfatla tavsif ederler ve onları dinî kişilere benzetir, tarihî ve mitolojik kahramanlarla kıyaslar ve memduhun üstünlüğünü savunurlar. Sâmih de Mustafa Paşa’yı "vezîr, müşîr, dilîr, müdîr, muhterem, din-perver..." gibi sıfatlarla tavsif eder ve zâtını Hz. Ali’ye, hayatını da Hz. Ebubekir'e benzetir. Sâmih, Mustafa Paşa'nın âlemlerin iftiharı Hz. Muhammed ile aynı adı taşıdığını da ifade eder. 
Sâmih daha sonra Mustafa Paşa'nın akıl, fikir ve düşüncesinin övgüsüne geçer. Feleğin dönmesi daima paşanın düşünce ve kastı üzerinedir. Zâtı düşünce ve aklın isnadının süsleyicisi, dergâhı hikmet ehlinin sığınağıdır. Hak, bilgi tahtını onun zâtıyla süslemiştir. Paşanın eşi benzeri bulunmayan zâtı, şan ve şeref hazinesine sahiptir ve o, varlı̆̆ın ıslah nüshasının düzenleyicisidir.

Kasidede memduhun methedildiği bir diğer yön de cömertliğidir. Allah onun kapısını, bütün halkın ihtiyacını gördüğü yer haline getirmiştir. Klasik Türk şiirinde cömertlik söz konusu olduğunda kıyas unsuru olarak Hâtem-i Tayî kullanılır. Divan şairlerinin kasidelerde "Tay" kelimesi üzerinden yaptıkları kelime oyununu Sâmih de yapmıştır. Hâtem, Tay kabilesinden olduğu için Hâtem-i Tayî diye ünlenmiştir. Tay kelimesi "dürüp bükme, sarma, katlama, silme, kazıma” anlamlarına gelir. Şairler bu iki anlamı kullanarak tevriye yaparlar. Cömertlik bahis konusu olduğunda Mustafa Paşa Hâtem-i Tayî’nin nâmını siler atar. Cömertlik ve ihsanı Allah ona tabiat olarak ihsan eylemiştir:

Țayy olur nāmı sehāavet mebḩașinda Ḥātemüñ

Cūd u iḥsānı Hü̈dā aña tabíc at eyledi

Sâmih, memduhun cesaret ve kahramanlığını göstermek için Paşa’yı İran mitolojik kahramanı Rüstem'le kyyaslar ve paşanın ondan üstün olduğunu söyler. "Eski şiirimizde kahramanlık, kuvvet ve yenilmezlik sembolü olarak özellikle kasidelerde anılan Rüstem, Cemşîd soyundan gelen Nerimân’ın torunu ve Sam'ın oğlu olan Sicistân ve Seyistân hükümdarı Zâl'ın oğludur." (Pala, 2003:395). Mustafa Paşa şecaat arsasında öyle bir at binicisidir ki Rüstem, Paşa'nın atının nalının altında merhamet ve himayesine sığınır.

Paşanın selametle avdeti ve Sırp meselesini çözmesi halk için mutluluk bayramı olmuş, halk tehniye yani "Hoş geldin!" demek ve paşayı tebrik etmek için ileri atılmıştır. Paşanın kudûmu ve adalet gölgesiyle halk mesrur olmuş, istirahat eylemiştir.

Sâmih 39. beyitle fahriye bölümüne geçer. Şair fahriyeye geçmeden önce methiyesindeki kusuru feleğe yükler. Takatsizliğini, gam hazinesine esir olduğunu, sıkıntısını kısacası hasb-i hâlini üç beyitte şöyle açılkar:

Çoḳ ḳuṣūr itdüm șenā vü medhüñode āṣafāa
Gerçi evșāfuñ Tecāāā bi-nihāyet eyledi

Ben yine medḥüñde itmezdüm ḳuṣūr ammā felek

Cevr-i bā-ḥusbānı ḥırmen-sūz-1 țāḳat eyledi

Mübtelā-yı deyn idüp itdi esīr-i genc-i ġam

Naḳd-i vaḳt-i ‘ ayşumu berbād-1 ḍacret eyledi

Sâmih fahriyesinde kendi sözlerini mucizeye benzetir. Hak, şairin feyz dolu gönlünü belagat madeni yapmıştır. Şair, nazmın cihanı süsleyen güneşi olunca o güneşin ışığı mana âlemine nur saçar. Eda ve şiveyi Sâmih'in düşünce güzeli öğretmiş, şairlik yaradılışından cihan tazelik kazanmıştır. Sâmih fahriyesinde kendini ünlü şair Hassan ile mukayese eder. Hassan, "Peygamberimiz zamanında yaşamış bir şairdir. Peygamberimiz onun için mescide bir minber yaptırmıştı. Hassan (633-680) oraya çıkar, müşrikleri yerip peygamberimizi överdi. Peygamberimiz ona 'Ruhul-kudüs (Cebraîl) sana yardım etsin.' 
diye duâda bulunmuş." (Pala, 2003:206). Sâmih’in şairlik yaradılışı Hassan’ın ününü unutturmuş, şöhreti ise geçmiş eserleri kaybettirmiştir. Gönül sultanı fesahat tahtını süsleyince nazm ülkesi tenafürden kurtulmuştur. Şairin fahriyesindeki iddialarının doğruluğunun hücceti kasidesi, mazmununun şahidi de gazelidir. Sâmih kaside ve gazelini sanatı için şahit kılar ve şu beyitle tegazzül bölümüne geçer:

Bu ḳașide hüücetümdür müdde` āmuñ ṣıdḳına
Bu gaazel ‘adl üzre mażmūnun şehādet eyledi

Kasidenin tegazzül bölümünde beş beyitlik rindâne bir gazel yer almaktadır. Gazelin muhtevası aşk, sevgili ve aşkın şair üzerindeki etkisidir. Şûh sevgili aşığın sabır ve rahatını yağmasıyla yerle bir ettiğinden "harâmî-zâde”ye benzetilir. Sevgili, ağyarı her zaman visal meclisinde mahrem ederken âşı̆̆ına firkat kadehi sunmuş ve onu ayrılık sarhoşu etmiştir. O zalim sevgili önce nezaketle vefa saçının ucunu göstermiş sonra da cefa yüzünü sunmuştur. Güzellik hakanının gözü fitne mülkünü alırken, gamzesi güzellik ülkesini teshir eder. Bunun üzerine şair gururlu sevgiliyle vuslat gününde yalnız kalma ümidini yitirir. Tegazzül bölümünden sonra aşağıdaki beyitle şair dua ve avdet için tarih düşmeye geçer:

İrdi pāyāna ḳașide hem gazel naẓm-āverān

Söz hitāmında du`āyı hị̂sn-i ‘ ādet eyledi

Sâmih’in Sultan Abdülaziz için duası, tahtında ber-karar olmasıdır. Çünkü padişah şer ve fesadın son bulmasını sağlamıştır. Mustafa Paşa için duası, ömrünün uzun olmasıdır. Çünkü paşa Sırp’ın ıslahında çok fazla gayret göstermiştir. Şair aşağıdaki son beyitle Mustafa Paşa'nın kudûmuna 1279 tarihini düşer:

Çıḳdı bir tārīh ḩāmem söyledi müjde diyü

Muștafā Paşa-yı ‘ ālì-nām ` avdet eyledi

Yukarıda da görüldüğü gibi Hocazâde Mehmet Efendi kudûmiyesi padişaha, yani Sultan Ahmet Han'a, Sâmih ise Müşir Mustafa Paşa'ya sunmuştur. Mehmet Efendi'nin kasideyi sunuş amacı "şehre teşrif" iken Sâmih'in sunuş sebebi "seferden dönüş"tür. Mehmet Efendi kudûmiyesinde sultanın önce Edirne'ye sonra da İstanbul'a gelişini “tasvir ve tahkiye” ağırlıklı işlemiştir. Sultan Ahmed’in Edirne'de neler yaptığını, nerelere gittiğini, teşrifiyle neler olduğunu anlatmıştır. Edirne'den sonra İstanbul'a teşrifini ve özellikle devlet ricalinin ve halkın coşkusunu, düzenlenen şenlikleri teşbih, mecazlarla tasvir etmiştir. Sâmih ise kudûmiyesinde yer yer seferden dönüşün etkilerini anlatsa da daha çok methiye yolunu izlemiştir. Mehmet Efendi'nin kudûmiyesinde sultanın hem Edirne'ye hem de İstanbul'a teşrifiyle ilgili herhangi bir tarih yoktur. Sâmih ise Mustafa Paşa'nın Sırp meselesini halledip gelmesine kasidenin son beytinde tarih düşmüştür.

\begin{tabular}{|l|l|l|}
\hline Kudûmiyelerin Muhteva Özellikleri & Mehmet Efendi & Sâmih \\
\hline Sunulan Kişi & Sultan Ahmed Han & Mustafa Paşa \\
\hline Sunuş Sebebi & Şehre Teşrif & Seferden Dönüş \\
\hline Makdem Şehri & Edirne ve İstanbul & İstanbul \\
\hline Kudûmiye Tarih & - & $1279 / 1863$ \\
\hline
\end{tabular}




\begin{tabular}{|l|l|l|}
\hline A ̆ğırlılı Üslup & Tasvir ve Tahkiye & Methiye \\
\hline
\end{tabular}

Tablo 2

\section{Metinler}

Kașīde-i Şeyhü'l-islām Muḥammed Efendi Berāy-1 Sulțān Aḥmed Ḩān

fầilātün fầilātün fằilātün fầilün

Huayr-maḳdem merḥabā ey dāver-i devr-i zamān

Āfitāb-1 țal' atuñla oldı nūrāni cihān

Zulmet-i firḳatde ‘ālem bìi-ser ü sāmān iken

Çeşme-i ' aynü'l-ḥayāt-1 vuṣlatuñ oldı ' ayān

Nice demlerdi ki gözlerdük gubār-ı maḳdemüñ

Rūşen itdi dīdemüz ol tūtiyā-yı çeşm-i cān

Çıkdı istiḳbālüñe iḳbāl ile cālem şehā

Pāyüñe yüz sürdiler 'izzetle a' yān-1 zamān

Yerde buldı gökde ararken felek mihr ü mehi

Gördi çün iki rikāb-1 dür-nişānuñdan nişān

Cānı geldi yerine şehrüñ ḳudūmuñla yine

Rūhısın sen `ālemüñ āfāḳa aḥkāmüñ revān

Oldı lerzān bìd-veş diller firākunla senüñ

Bāğ u rāğa ug̣radıḳda berg-i rīiān-1 ḩazān

Ḥamdülillāh şimdi nīsān-1 seḥāb-1 lüṭ̂ ile

Bā g̀-1 ḳalbüñ oldı her bir gūşesi bir gülsitān 
Eyleyüp ‘ azm-i diyār-1 Edrine ey şāh-1 dīn

Devlet ü iḳbāl ile egleñdüñ anda bir zamān

Virüp ol tahtt-1 ḳadīme maḳdemüñ tāze şeref

Oldı ābādān ḳudūmuñla o köhne hānedān

Nola sa' $d$ olursa ol şehre duhūlüñ yümn ile

Ṭog̀rı beytullāha indüñ ey güzīin-i dāverān

Eyleyüp cāmi` leri ị̣yā edā-yı farż ile

Șu gibi her cum ada bir cāmi` e oldun revān

Kande olursañ idersin çünki bir ma` bed binā

Yapduñ ol dār-1 sa' ādet içre bir mescid hemān

Cūy-i Tunca aḳdı pāy-ı ḳāmet-i dil-cūyuña

Kayı̀guñ üstinde anuñ oldı bir taḥt-1 revān

Șafḥa-i șaḥn-1 serāyuñda o cūy-1 ḩoş-nümā

Bir gümüş cedvel çeküp sīm-i müzāb itdi revān

Șayd-gāhında idüp seyr ü şikār ol kişverüñ

Kalmadı bir gūşe-i zībāsı kim ola nihān

Ẓāhirā ‘azm-i şikārı āşikār itdüñ velī

Fi'l-ḥaḳiḳā eyledüñ ḳaṣd-1 şikārı ẓāhirā

Șūretā geşt ü güzār itdüñ egerçi cālemi

Dād-h̆ॅ̄āhı diñlemek ḳașd eyledüñ andan hemān

Baṣmamışdı nice demlerdi o zỉbā kişvere

Pāy-1 rahş̧-i āsumān-naḳş-1 hidīīān-1 zamān 
Bașıcaḳ ol mülke devletle semend-i himmetüñ

Naḳş-i nac lüñ eyledi rūy-1 zemīni āsumān

Oturup iclāl ü devletle beş ay ol beldede

Şeş-cihetden geldi cem` oldı cünūd-i bì-gerān

Șoñra da şehr-i Geliboluya iḳbāl eyleyüp

Eyledüñ ol āşiyān-1 fetḥ ü nuṣrı āsitān

Șoñra devlet ile Kilid Baḥri seyrān eyleyüp

Eyledi miftāḥ-1 cūduñ fetḥ-i bāb-1 baḥr ü kān

Fitne-i Ye 'cūc-1 küfr içün urur sedd-i sedīd

Oldı manẓūruñ nice muḥkemdür ol dār-1 emān

Eyleyüp evc-i burūcı saḳf-1 gerdūna 'urūc

Kubbe-i çarh-i felekden ḳullesi virmiş nişān

Ol hịșar-1 üstüvārı seyreden ma lūm olur

Dīn yolunda nice hiidmet eylemiş ' Oṣmaniyān

Taḩt-1 baht üzre mekīn olsun eyā sultạn-1 dīn

Oldugunca maẓhar-1 gufrān-1 Haḳk ol serverān

Ol iki ḥıṣn-1 ḥașinuñ emr idüp ta` mírine

Eyledüñ imdād-1 dīn ey dāver-i devr-i zamān

İki günde yine ‘avdet eyleyüp iḳbāl ile

Sāye-i elțāfuñı ol şehre itdüñ sāye-bān 
Yazıcıog̀lın ziyāret eyledüñ ikrām ile

Āb-1 feyż ola revānından saña dā 'im revān

Çünki eyyām-1 vilādetde ziyāret eyledüñ

Mevlid oḳutduñ ḳabūl ide Hüdā-yı müste`ān

Yümn içün șoñra Süleymān Şāh-1 Gāāìye varup

Seyf-i fetḥ ü nuṣreti ḳuşanduñ ey șāḥib-ḳırān

Eyleyüp andan ' azīmet āsitān-1 devlete

Geldüñ İstanbula tọgrn ey mu ỉn-1 rāstān

Avladuñ şāhīn-i himmetle şehā hāān-zādeyi

Beste-i fitrāḳ-1 lüṭf oldı yine ol nev-cüvān

Pādişehler șayd-1 nahcīi eylemişler șayd ile

Avladuñ şāhīni sen ey şāhbāz-1 serverān

Semt-i istikbāle isti` cāl idüp iḳbāl-veş

Hualḳ-1 'ālem oldılar hep rāh-1 ḩıdmetde devān

İtmege kuhl-1 cilā-yı çeşm-i cān ḩāk-1 rehüñ

Nergis-āsā yollara göz dikdi ac yān-1 zamān

Hamdülillāh kim gelüp ey dāver-i ‘ālem yine

Rūşen oldı nūr-1 vechünle 'uyūn-1 dā' iyān

‘ Ālimān-1 dīn olan dā‘ ìler ile cümleten

Yüz sürüp dāmānuña olduḳ ḳarīn-i ‘ izz ü şān

Menzil-i māh-1 şeref oldı Küçükçekme bize

Kim göründi anda māh-1 rūy-1 sulțān-1 cihān 
Ol gice bulup şeref Dāvūd Pāşā menzili

Ol feżāda ḳondı cümle leşker-i İslāmiyān

Maḳdem-i şāh-1 cihāna cümle şenlikler idüp

İtdiler peydā o gice mūmlardan çādırān

Mumlar ile zeyn olup ordu-yı dil-cū ser-te-ser

Yir yüzinde āşikār oldı rusūm-1 ahterān

Ḩayr maḳdem dimek içün ey meh-i burc-1 şeref

İtdiler gūyā zemīne āsumāndan rūşenān

Çünki emrüñle şehā ol şeb çerāgāan itdiler

Șanki geldi bir yire şeb-çerāgāan-1 zamān ${ }^{6}$

Lāleler șaḥn-1 çemenzār içre meş aller yaḳup

Oldılar ol leylede anlar dahı āteş-feşān

Göklere irüp o gice şevḳden șit ü șadā

$\mathrm{Na}^{c}$ ra-i ț̣p u tüfekden güm güm itdi āsumān

Kal' a-i ẓulmet-nümā-yı fürḳati fetḥ itmeğe

Ol gice çalışdılar gūyā cemíc $-i$ ins ü cān

Şām-1 vaṣl-encām-1 hicri def ${ }^{\Upsilon}$ idüp sulțān-1 șubh

Çın sehẹerden 'arż-1 dīdār itdi şāh-ı hạaverān

Dizilüp șaflar alaylar bağlanup tertỉb ile

Cem` olup hayl-i beşer gösterdi mahş̧erden nişān

Misrada bir hece eksiktir. 
Ṭonanup elvān-1 bayrakla sipāh-1 şāh-1 dīn

Ṣaḥn-1 ṣaḥrā içre gūyā lālezār oldı ‘ ayān

Surh u zerd ü al idüp dāmānını pervāz ider

Oldı pervāzīsi anuñ ṣanki țāvūs-ı cinān

Sebzezārn itdi tezyīn gūne gūne lāleler

Virdi rengārenk bayraḳlarla ordudan nişān

Șaḥn-1 ṣaḥrāya yeşil mahumil yapup ferrāş-1 șubḥ

İtdi pāy-endāz-1 esb-i dāver gibi sitān ${ }^{7}$

Baġladı șaflar dırahtān-ı çemen șaf saf țurup

Sāye șalar diyü bāga ol ḳad-i serv-i revān

Maḳdem-i sulțān-1 devrāna nisār olsun diyü

Dökdi varın rāh-1 gülzāra nihāl-i erg̉avān

Ṭaḳınup tìg-i zümürrüd-fāmı sūsenlerine

Aldılar debbūslar dūşa mis̄āl-i çāvuşān

Altun üsküf başda destinde zümürrüdden ' așā

Oldı zerrīn saña derbān ey şeh-i sāmīi-mekān

Açdı zanbaḳ aḳ sancaḳlar livā-yı șubḥ-veş

Rāyet-i fetḥ āyetüñ şevḳiyle ey şāh-1 zamān

Tūg̀-1 şāhı ḳad çeküp açıldı șaḥn-1 bāg̉da

Ṣanki çözdi perçem-i tūguñ ṣabā olup vezān

Vezinde aksama vardır. 
Mā-hasạal bu vech ile zinet bulup ṣaḥn-1 zemīn

Maḳdemüñ şevkiyle țonandı şehā ehl-i zamān

Yüz țutup ‘ālem serāy-1 devlete iḳbāl ile

Baḳdılar kim gün gibi țog̉a şehenşeh-i cihān

Şāh-1 şāhān-1 zamān huāḳān-1 İskender-nişān

Ya ni kim Sulțān Aḥmed Huān-1 gerdūn-āsitān

Ola hem-vāre sipihr-i devlete mihr-i münīr

Āfitāb-1 tạl' atinden ola nūrāni cihān

Hualḳ iderken mațla` -1 bāb-1 hümāyūna naẓar

Āfitāb-1 ‘ālem-ārā gibi tọgdı nāgehān

Nūr-baḥş olup cemāl-i bā-kemāli ‘ āleme

Virdi piş̧ānisi tāb-1 mihr-i enverden nişān

Yayılup nūr-1 sürūr āfāḳa rūyından yine

Zulmet-i endūh u mihnet oldı şeb gibi nihān

Aḳlar geymiş ser-ā-pā māh rūyi berḳ urup

Nūrdan bir cism-i pāke dönmüş ol mihr-i cihān

Ol elif ḳadd çün selāma egdi başın lüṭf ile

Karşusında lāma döndi kạāmet-i islāmiyān

Ḩāk-i pāyinde gidüp erkān u a yaān cümleten

Geldi vaḳt-i zuhrede virdi serāya 'izz ü şān

Mihr irdikde maḥall-i istivāya gün gibi

Müstevi oldı serīinde şehenşeh-i zamān 
Yolda a' yānı rikābıyla müşerref eyleyüp

Bu kemine bendesinde itdi lüțfı hem- ' inān

Gūş-i hūşum sözleri dürrine olmuşken șadef

'Arż-1 İslām eyledi bir kāfir anda nāgehān

Maḥżarında dīn-i islāmı aña telḳin idüp

Ṭūl-i ‘ ömr ü devleti içün du`ā itdüm hemān

Ol şehenşeh-i cihān içün ugur tutduk eli

Dā'imā devrinde arta zümre-i ỉmāniyān

Çün der-i dār-1 sürūra geldi ‘ izz ü şān ile

İtdi fermān-1 du ā ol dāver-i șāfī cān ${ }^{8}$

Ṭūl-i ` ömr ü devletiyçün eyledük anda du` à

Umarız ola ḳarīn-i da`vet-i kerrūbiyān

Ṣıdḳ-1 niyyet șāḥibidür çünki ol sulțān-1 dīn

Müstecāb ide du āmuz hāā1ḳ-1 kevn ü mekān

Maẓhar-1 iḥsānuñ olmuşdur MUḤAMMED serverā

Nola olsa midḥatüñle dā'imā rațbü'l-lisān

Çün ider şīīn edālarla hemiş̧e vașfuñ

Dā 'imā olur zebān-1 ḩāmesi ‘ażbü’l-beyān

Şekker-i şükrüñ neyistānında şekker-ḩā olur

Hāmesi ṭūtị-ṣıfat olsa nola şīīin-zebān

Misrada bir hece eksiktir. 
Zer gibi hāliṣ-` ayār oldur hulūṣ-1 ḳalb ile

Ġ1ll ü ġışdan ṣāf ü pāk olur olursa imtihān

Dā 'imā āb-1 ḥayāt-1 zindegānī nūş idüp

Devlet ü iḳbālüñ artup ola 'ömrüñ cāvidān

\section{Kașīe vü Tārihh-i 'Avdet-i Sa' d-Menḳabet-i Ḳumandān ü Vālì-i Eyālet-i Üsküb Ḥażret-i Muștafā Paşa “Māyürīdü Mā Yeşā” Ez-Mes ’ele-i Șırb Der-Medīne-i Prizren}

fācilātün fācilātün fācilātün făcilün

Dīni nuṣretle Hudā iḥyā irādet eyledi

Ḥażret-i `Abdul' aziz Hูāna `ināyet eyledi

' Ālem olmuşken esīr-i pister-i derd ü helāk

Maḳdemi el-ḥaḳ devā-bahş-1 ifākat eyledi

Ol şehenșeh-i mu`a azzam ol şeh-i vālā-himem

Dest-i lüțfin sāyebān-i ra`iyyet eyledi

Bād-1 nașr u fevz itmekde biḥamdillāh vezān

Gülşen-i ‘ ālem zihì kesb-i țarāvet eyledi

Kalmadı āyīne-i mülk üzre āṣār-1 gubār

Revnaḳın buldı cihān def ${ }^{\complement}$-i küdūret eyledi

Kalmadı şübhe müceddid oldıġın ol Hüsrevin

Ān-be-ān meşhūd olan ḥālet delālet eyledi

Tāb-1 ' adlinden o huāḳānuñ ' adem-ābāda dek

Zulm ü şer bīm ü hirāsından ` azìmet eyledi 
Yādına gelmez zamānında fiten bir kimsenüñ

Gerçi Șırbistān țugyaāna cesāret eyledi

Kār-fermā bir verzirine o şāh-1 nìk-baht

Bu işin itmāmını emr ü işāret eyledi

Ol vezírin eyleyüp ya`ni ḳumandān-1 cünūd

Seyf der-ḳabż olmadın düşmān ițāa at eyledi

Bir vezīrdir kim vezīi ammā vezìi ibn-i vezìir

Hak yed-i te'dībine mülki emānet eyledi

Hem vezīr ü hem müşì ü hem dilìi ü hem müdìr

Hạ bu evșāfi aña ancaḳ ' ināyet eyledi

Nām-daş-1 mefhar-1 ' ālem hidīiv-i muhterem

Zāâtı Ḥaydar sīretin Șıddiḳ-hașlet eyledi

Ol ḳumandān-1 şecāe`at-iḳtirānun himmeti

Ṣırb-ber-Ṣırb iş içün kesb-i suhūlet eyledi

Gördi tedbīr-i dilīr-i āsafı kennāz-1 Șırb

Der-` aḳab irsāl-i esfār-1 nedāmet eyledi

Ḥamd ola ol gàa 'ile dünyādan oldı ber-țarāf

Ol vezīr-i dīn-perverdür ki gayret eyledi

Nice yıldur ki ahālì-i ḳı $1 \bar{a}^{`}-1$ Belgrad

Hูavf-1 düşmāndan ne ārām ü ne rāḥat eyledi

Maḥż-1 re 'y-i șầ 'ibindendür o kān-1 şefḳatiñ

Ehl-i ỉmān yerlerin cāy-1 selāmet eyledi 
Kārı bu emr-i ' aẓimüñ çend-māh içre hemān

Ol hidīvüñ himmetiyle hüsn-i gāayet eyledi

Mevḳi ${ }^{`}$-i taḥsini tezyin eyleyüp bu ḩıdmeti

Şükr ü sābāşıı bütün erkān-1 devlet eyledi

Nice erkān itmesün zāâtıyla lillāh iftiḩār

Kimdür āyā dīn ü mülke böyle hidmet eyledi

Zāâtını himmetle ḳ̂ldı maṭlac -1 naẓm-1 șenā

Nāmını ser-levḥa-i divān-1 rıf ${ }^{\complement}$ at eyledi

Ṭab` 1nı ser-nāme-i mecmu` a-i fażl ü kemāl

Hulkını dībāce-pīrāy-i fețānet eyledi

Her ne emr itse ḳader îfāsına eyler şitāb

Her ne hükm itse każāa icrāya sür` at eyledi

Naẓra-i ūlāda eyler cevher-i ferdi dü-nīm

Ḥikmet-i Ḥaḳ 'aḳl ü fikrin cāy-1 ḥayret eyledi

Yüz ḳoyup hāk-1 derinde i' tirāfa Bū 'Alì

Da'vi-i hịkmetde iẓhār-1 nedāmet eyledi

Re 'y ü ḳaṣdı üzredür devri sipihrüñ dā 'imā

Emrine sükkān-1 heftümīn ițā' at eyledi

Zāatıdur pirāāye-bahşs-1 mesned-i re'y ü hured

Dergehin Bārī melāzz-1 ehl-i ḥikmet eyledi 
Āsitānın ḳıldı Haḳk hạacet-revā-yı hās u 'ām

Āstīn-i ekremin ceyb-i semāḥat eyledi

Ṭayy olur nāmı sehāvet mebhașında Ḥātemüñ

Cūd u ị̣sānı Hüdā aña tabī at eyledi

Āṣafā bende-nüvāzā serverā dād-āverā

Zaātuñ mevlā medār-1 kār-1 devlet eyledi

Sensin ol destūr-1 ‘ ālì-menḳabet kim tā ezel

Haḳk serīir-i dānişi zāâña zīnet eyledi

Sensin ol eşheb-süvār-1 'arșa-i şecā' at kim

Zīr-i na` 1 -i esbüñe Rüstem dehālet eyledi

Sensin ol şīāze-bend-i nüsḩa-i 1ṣlāḥ-i kevn

'Aḳluñı Feyyāż miftāḥ̂-1 dirāyet eyledi

Gevher-i nā-yāb-1 zātuñ ile pür-zerrīn yine

Hāàiz-i gencīne-i şān ü şerāfet eyledi

Ġurre-i garrā-y1 yümn-i ‘ avdetüñ ey mihr-i şān

Hep görenler hạk bu kim ‘ id-i meserret eyledi

Geldi paşamuz biḥamdillāh selāmetle diyü

Birbirin halk tehniye itmekde sebḳat eyledi

Nice mesrūr olmasun 'ālem ḳudūmuñdan senün

Sāye-i ‘ adlüñde herkes istirāḥat eyledi

'Afvuña mağfūr olup böyle perişsān-zihn iken

Ḩāme evșāfuñda bir ḳaç söz kitābet eyledi 
Çoḳ ḳuṣūr itdüm șenā vü medḥüñde āṣafã

Gerçi evșāfuñ Te $\mathrm{Te}^{c}$ āā bì-nihāyet eyledi

Ben yine medhüñ̃de itmezdüm ḳuṣūr ammā felek

Cevr-i bā-ḥusbānı ḥırmen-sūz-1 țậat eyledi

Mübtelā-yı deyn idüp itdi esīir-i genc-i gam

Naḳd-i vaḳt-i ‘ ayşumu berbād-1 żacret eyledi

Yohsa ben bir şā‘ ir-i mu ciz-beyānum kim benüm

Ḥaḳ dil-i pür-feyżümi kān-1 belāgat eyledi

Ben o hưrşid-i cihān-ārā-yı naẓmum pertevüm

' Ālem-i ma` nāyı pür-nūr ü iżā'et eyledi

Şāhid-i endiş̧em ögretdi edā vü şiveyi

Şūḥ-1 țab umdan cihān kesb-i terāvet eyledi

Hüsn-i țab` um șìt-i Hassānı unutdurdı benüm

Şöhretüm āsāâr-1 eslāfı iżā̄ at eyledi

Zìver-i taht-1 feșāhat olalı sulțān-1 dil

Kişver-i naẓmum tenāfürden berāe ${ }^{`}$ at eyledi

Bu ḳașide hüuccetümdür müdde āmüñ șıdḳına

Bu gazel ` adl üzre mażmūnun şehādet eyledi

Șabr u sāmānum amān bir şūh gāàret eyledi

Ol ḥarāmī-zāde baḳ baña ne ḥālet eyledi 
Eyleyüp aġyārı her dem mahrem-i bezm-i vișāl

'Āşıḳın sermest-i hicr ü cām-1 firḳat eyledi

Gösterüp evvel nezāketle ser-i zülf-i vefā

Șoñra ol ẓālim cefā rūyın irā 'et eyledi

Çeşmi ol hāḳān-1 hüsnüñ aldı mülk-i fitneyi

Ġamzesi teshīir-i büldān-1 melāḥat eyledi

SĀMİHĀĀ ol yār-1 nahvet-perverüñ bī-çāre dil

Rūze-i vaṣlın taḩallìden ferāgat eyledi

İrdi pāyāna ḳașide hem gazazel naẓm-āverān

Söz hitāmında du` āyı hüsn-i ‘ ādet eyledi

Ber-ḳarār itsün Huudā tahtında şāh-1 a' z̧amı

Gerdiş-i çarḩ-1 fesād ü şer sükūnet eyledi

' Ömrin efzūn ide ol destūr-1 żi-ḳadrüñ dahı

Șırbuñ 1ṣlāḥında bezl-i sacy ü miknet eyledi

Çıḳdı bir tārihh hāmem söyledi müjde diyüp

Muștafā Pāşā-yı ‘ àlì-nām 'avdet eyledi

Sene 1279

Naẓmühā ve raḳamuhā el-faḳirü'l-ḥaḳiir ilā keremi rabbü'l-ḳadīr Naṣuhhī-zāde hafaīdi merḥūm veḳāyi kātibi İbrāhīm İffet Efendi hafīdi Es-seyyid Muhammed Sāmih İ̉n-i Çāvūş-zāde Muhammed 'Azīz el-müderrisi be-dārü's-salṭanatü's-seniyye el-müvellāhilāfeti be-medineyi Prizren gaferahüm.

\section{Sonuç}

Klasik Türk edebiyatı içerisinde yer alan edebî türlerden biri de kudûmiyelerdir. Kudûmiyelerin ilk örneklerine 14. yüzyılda rastlanmaktadır. 15. ve 16. yüzyıllarda çeşitli şairler tarafından bu türde örnekler verilmiş, tür asıl gelişimini ise 18. ve 19. yüzyılda göstermiştir. Kudûmiyeler genellikle şairler 
tarafından din veya devlet büyüklerinin seferden dönmesi veya bir şehre teşrifini kutlamak, onları övmek amacıyla yazılan şiirlerdir. Bu çalışmada 17. yüzyıl şairlerinden Şeyhülislam Muhammed Efendi'nin ve 19. yüzyll şairlerinden Sâmih’in kudûmiyeleri mukayeseli olarak incelenmiştir. Şeyhülislam Muhammed Efendi'nin eserini Sultan I. Ahmed'in 1021 (1612/1613) yllında Edirne'ye teşrif ettiğinde, Sâmih'in ise kasidenin sonundaki tarih beytinden 279 (1863) yılında yazdığı anlaşılmıştır. Her iki şairin kudûmiyesi de kaside nazım şekliyle ve remel bahrinin "fầilâtün fầilâtün fâ’ilâtün fầilün" kalıbıyla yazılmıştır. Şeyhülislam Muhammed Efendi’nin 83 beyitlik kudûmiyesinde "mürdef" kafiyeyi, Sâmih'in 57 beyitlik kasidesinde ise mü'esses ve mücerred kafiyeyi görürüz. Şeyhülislam Muhammed Efendi'nin kudûmiyesi klasik Türk edebiyatı kaside nazım şeklinde gördüğümüz bölümleri ihtiva etmemektedir. Sâmih'in kudûmiyesi ise "methiye, fahriye, tegazzül ve dua" bölümlerinden oluşmaktadır. Her iki şairin de kudûmiyeye verdikleri başlık kasidenin muhtevasına gönderme yapar.

Şeyhülislam Muhammed Efendi'nin kudûmiyesi I. Ahmed'in Edirne'ye teşrifi ve İstanbul'a dönüşü üzerine, Sâmih'in kasidesi ise başlıkta belirttiği gibi Mustafa Paşa'nın Sırp meselesini halledip seferden dönüşü üzerine yazılmıştır. Muhammed Efendi’nin eserinde Sultan Ahmed Han'ın Edirne şehrine gelişi ve ayrıca İstanbul'a tekrar dönüşü istikbal edilirken Sâmih'in eserinde Mustafa Paşa'nın seferden İstanbul'a dönüşü kutlanmaktadır. Şeyhülislam Muhammed Efendi kudûmiyesinde ağırlıklı olarak "tasvir ve tahkiye" üslubunu kullanarak Sultan I. Ahmed'in Edirne'ye gelişi, burada yaptıkları ve tekrar İstanbul'a dönüşünü anlatır. Şair, sultanın nerelere gittiğini ve neler yaptığını tasvir ederken aynı zamanda sultanı metheder. Sâmih ise kudûmiyesinde ağırlıklı olarak divan şiiri methiye geleneği anlayışıyla Mustafa Paşa'yı över. Şair, kudûmiyesinde methiye ile birlikte seferden muzaffer olarak dönüşün halk üzerindeki etkisini de vermeye çalışmıştır.

\section{Kaynakça}

Akkuş, Metin (1993). Nefî Divanı. Ankara: Akçağ.

Akkuş, Metin (2007). Klasik Türk Şïrinin Anlam Dünyası Edebi Türler ve Tarzlar. Erzurum: Fenomen Yayınları.

Aydemir, Yaşar (2004). Methiye. TDV İslam Ansiklopedisi (C. 29, S. 410-411). Ankara: TDV.

Çalışkan Nurettin \& Ünal, Mehmet (2018). Mehmet Sâmih'in Üsküp Valisi Müşir Mustafa Paşa Medhiyesi Bağlamında Bir Tarihi Dönem İncelemesi. Uluslararası Sosyal Araştırmalar Dergisi, $11 / 61,64-75$.

Çiftçi, Ömer (1996). Fatîn Davud Hâtimetü’l-Eş’âr (Fatîn Tezkiresi), Yüksek Lisans Tezi, İnönü Üniversitesi, Malatya.

Devellioğlu, Ferit (2004). Osmanlıca-Türkçe Ansiklopedik Lûgat. Ankara: Aydın Yayınları.

Ertuğrul, Züleyha Nurgül (2018). Klasik Türk Edebiyatında Kudûmiye. Yüksek Lisans Tezi, Gazi Üniversitesi, Ankara.

İnal, İbnü’l Emîn Mahmud Kemal (1988). Son Asır Türk Şairleri III, İstanbul: Dergâh Yayınları.

İpşirli, Mehmet (2003). Mehmed Efendi Hocazâde. TDV İslam Ansiklopedisi ～(C. 28, S. 452-453). Ankara: TDV.

Kocakaplan, İsa; Gökalp, Haluk; Aça, Mehmet (2012). Başlangıçtan Günümüze Türk Edebiyatında Tür ve Şekil Bilgisi. İstanbul: Kesit.

Küçük, Sebahattin (2018). Bâkî Divanı. http://ekitap.kulturturizm.gov.tr, (Erişim Tarihi: 01.01.2018).

Mehmed Süreyya (1996). Sicill-i Osmanî 5, (Haz: Nuri Akbayar), İstanbul: Tarih Vakfı Yurt Yayınları.

Odabașı, Mihrican (2009). Tuhfe-i Nâilî Metin ve Muhteva, Yüksek Lisans Tezi, Cumhuriyet Üniversitesi, Sivas. 
Ölmez, Ahmet (1996). Behceti Hüseyin Efendi Divan (Hayatı-eserleri ve Divaninı Tenkidli Metni). Doktora Tezi, Erciyes Üniversitesi, Kayseri.

Pala, İskender (2003). Ansiklopedik Divân Şïri Sözlüğü. İstanbul: L\&M Yayınları.

Sami, Şemseddin (2009). Kâmûs-ı Türkî, İstanbul: Çağrı Yayınları.

Tuğluk, Halil İbrahim (2010). Divan Şiiri’nde Manzum Tebrik-nâmeler. A. Ü. Türkiyat Araştırmaları Enstitüsü Dergisi, 42, 41-68.

Tuman, Mehmed Nâil (2001). Tuhfe-i Nâilî-Divan Şairlerinin Muhtasar Biyografileri II, (Haz: Cemal Kurnaz, Mustafa Tatcı), Ankara: Bizim Büro Yayınları. 